\title{
The Gender STEM Gap and Its Impact on Sustainable Development Goals and the Big Four Agenda in Kenya: A Synthesis of Literature
}

\author{
Jane Amunga ${ }^{1}$, Amadalo Maurice Musasia ${ }^{2}$ \\ ${ }^{1}$ Department of Educational Foundations, Psychology and Management, Faculty of Education and Social Sciences, \\ Kaimosi Friends University College, Kenya \\ ${ }^{2}$ Department of Curriculum and Instruction, Faculty of Education and Social Sciences, Kaimosi Friends University \\ College, Kenya \\ Correspondence: Jane Amunga, Department of Educational Foundations, Psychology and Management, Faculty of \\ Education and Social Sciences, Kaimosi Friends University College, Kenya.
}

Received: Sep. 3, $2020 \quad$ Accepted: Oct. 5, $2020 \quad$ Online Published: Oct. 11, 2020

doi:10.11114/ijce.v4i1.5042 URL: https://doi.org/10.11114/ijce.v4i1.5042

\begin{abstract}
Women have made significant progress in education through marked increase in enrolment. However, the same zeal has not been demonstrated in STEM based subjects and careers. The gender STEM scale still tips in favour of men in many countries across the world. This imbalance in the STEM fields owing to dominance by men is what creates the STEM Gap. In this paper, we synthesize literature and secondary data to show these disparities. We appreciate that STEM gap drivers are numerous and therefore zero in on what we consider the critical STEM gap drivers with respect to Kenya. We identify and succinctly discuss these critical drivers which are: self-concept and lack of resilience, teachers' and parental expectations, role models and stereotyping, work environment and family obligations and finally weak scholastic performance. We also assess how this gender STEM gap is likely to affect the achievement of a number of Sustainable Development Goals (SGDs) and the Big Four Agenda and in the process, steer the country away from the path of industrialization envisaged in Vision 2030. We explain why it is important to mitigate the STEM gap and get more women in STEM. We recommend that, parents should deconstruct their own stereotypes; teachers should debunk the myth about STEM being the preserve of superior mental abilities that girls lack, students should acknowledge that STEM drives the economy and opens up employment opportunities, institutions should have a STEM endowment fund and industries should institute policies that enhance retention of women in STEM careers. It is expected that these if addressed should enhance women's participation in STEM based subjects so that they can build careers in STEM.
\end{abstract}

Keywords: gender STEM gap, sustainable development goals, big four agenda and drivers

\section{Introduction}

The STEM acronym was coined in the 1980s although the United States had demonstrated keenness on STEM related fields as early as the 1950s. This acronym refers to Science, Technology, Engineering and Math (Beede, et al, 2011). The imbalance in the STEM fields owing to dominance by men is what creates the STEM Gap (Silva, 2019). Although there is seemingly near gender parity in enrolment at lower education levels, by graduation, men outnumber women in all science fields (Genoways, 2014). According to Corbett, Hill \& St. Rose (2010), women enrolment at graduate level declines and further reduces during the transition to STEM related jobs. Therefore, although there has been gradual increase in the number of women in STEM over the years, the gender STEM scale still tips in favour of men in many countries across the world.

Globally, the STEM gap might not be alarming if the 2016 Gender Gap Report's figure of 47\% (Kimotho, 2019) is anything to go by. However, UNESCO (2019) and UNESCO (2017) report that, only 35\% of STEM students in higher education globally are women. Of these few women who choose STEM related fields, only 5\% take natural science, mathematics and statistics, while $8 \%$ take engineering, manufacturing and construction, and 3\% take information and communication technology (Willams, 2020). UNESCO (2017) further reveals that, only 17 women have won a Nobel Prize in Physics, Chemistry or Medicine compared to $572 \mathrm{men}$. A close examination of a number of countries reveals a different picture altogether. In the US women account for only $22 \%$ of the STEM work force and are responsible for only 16\% of granted patents (Mckenna, 2018). Hango (2013) reports that in Canada women accounted for 39\% of the 
university graduates aged 24-34 with a STEM degree in 2011. Despite this seemingly appealing percentage, only $23 \%$ graduated from engineering. Five years later, the National Girls Collaborative (2020) report revealed no significant improvement because in 2015, $18 \%$ of women graduated in computer sciences, $20 \%$ in engineering and $39 \%$ in physical sciences. Consequently, women remained underrepresented in the science and engineering work force at $28 \%$. It is further reported that Canadian women were unlikely to pursue higher paying jobs like engineering and computer science (Frank, 2019). In China, the statistics of National Universities showed that most boys major in the STEM subjects and that they account for $80 \%$ of the enrolment while female students cluster in social sciences (He, Zhou, Salinitri \& Xu, 2019).

Regionally, there is a general underrepresentation of women in science practice according to Okeke et al. (2017) whose study indicates low enrolments of female students in science courses 10 flagship African universities. This observation is echoed by the World Economic Forum report of 2016 which showed that, 30\% of male students were graduating from STEM programmes against $16 \%$ of female students (White, 2020). African countries are generally the most affected by the unequal gender participation in STEM. This is why the African Union called on Africa's political leadership to address this anomaly in demonstration of seriousness about embracing STEM for transforming their societies (Kimotho, 2019). In West Africa, no country has reached the $25 \%$ mark for women researchers in sciences (Okeke, et al., 2017).

Kenya, like most African countries has an immense shortfall of expertise in STEM fields at all levels of education (Rajput, 2019), and as Nyayieka (2019) discloses, there were 21, 400 professional women in science and technical fields against 52,400 men in 2017. Mbirianjau (2018) rates female participation in STEM at public universities in Kenya at less than 30\% despite the affirmative action. The 2019/2020 placement results by the Kenya Universities and Colleges Central Placement Service (KUCCPS) shows that, of the 57,687 students who enrolled for Science, Technology, Engineering and Mathematics (STEM), courses, 63 per cent were male and 37 per cent female (Obiria, 2019). This shows some improvement but which is still way below par. In institutions that track and stream girls according to ability, most girls end up in arts oriented courses and are thus tracked away from science and math throughout their educations, limiting their training and options to go into these fields as adults.

\section{Objectives}

The objectives of this review were:

1. To identify the critical STEM gap drivers

2. To assess the possible impact of the STEM gap on Sustainable Development Goals and the Big Four Agenda in Kenya

3. To suggest why the STEM gap drivers should be mitigated

\section{Methodology}

This paper adopts a desk top synthesis of literature from diverse sources. In addition, the most recent secondary data from the Kenya National Examinations Council (KNEC) and the Kenya National Bureau of Statistics inform the findings herein. This review offers great insights into the general and specific STEM gap drivers.

\section{Findings}

\section{Critical STEM Gap Drivers}

Factors militating against women's participation in STEM based subjects and careers are numerous and widely documented. However, this review identified the following key gender STEM gap drivers that resonate with the Kenyan situation:

\section{i. $\quad$ Self-Concept and Lack of Resilience}

Girls are generally socialized to assign a high premium on family. This expectation for a future family life and professions that are family flexible (Frome, Alfred, Eccles \& Barber, 2006) are more appealing to the girl-child but unfortunately either lack the STEM component or it is low. This very expectation unfortunately crowds them in the social sciences which they deem more feminine as opposed to STEM which they perceive as being more masculine. This thinking in turn leads to a low self-efficacy that is internalized early in life. Consequently, girls underestimate their own abilities in STEM compared to boys, raise their own bar (Corbet, Hill \& St. Rose, 2010), and insulate their own minds and brains against STEM. Studies have shown that, there are no significant differences in math abilities of boys and girls. Additionally, when girls persist in science fields, they excel academically (Williams, 2020). However, many girls lose confidence in Maths by the time they are in third grade while boys on the other hand will harbor the feeling of being strong by second grade. This usually happens even before any noticeable performance differences (Ibid). Few girls who enroll in STEM based courses have the mettle to push to career levels. As a result, there is a high attrition rate of the few women in STEM fields because most of them leave in disproportionate numbers during higher education 
studies and their career cycle (UNESCO, 2017). While most men are risk takers, women would love to take calculated risks whose flip side means not taking the risk at all. Men would rather try and fail, and in the process learn, but women's fear of failure keeps them away from STEM fields. Women who find themselves lone rangers in masculine environments feel uncomfortable (Baxter, 2010; Simon, Wagner \& Killion, 2017). Such women may decide to change courses so that they can operate in more accommodating environments away from STEM fields.

\section{ii. Teachers' and Parental Expectations}

Teachers and parents impact learners and children powerfully. Studies show that, parents and teachers strongly influence girls' perceptions as well as engagement in STEM. This is because their word is treated as gospel truth by learners and children in the early formative years of childhood. When they plant anti-STEM seeds, they sprout, grow and flower. The end result is that, female learners internalize the thinking that, STEM is for intellectually superior. This is despite the fact that, research shows STEM gap is not the result of differences in brain structure and development, genetics or innate ability (UNESCO, 2017). Genoways (2014) discloses how being told from a young age that, girls are not good at Maths undermines their performance and interest in STEM fields. They regard STEM as masculine, believe that they have inferior ability, and settle for courses they consider less intellectually demanding.

Teachers' differential treatment of male and female students also contributes to the reluctance of female students to take STEM. Literature shows that, teachers reinforce gender biases through their expectations of their own students (Clandfield \& Martell, 2014; Makarova et al., 2019). Ng'ang'a, Mureithi and Wambugu (2018) found that, because of girls' mien, teachers might have greater expectations of boys than girls and demand higher academic achievement which in itself sharpens the intellect. Girls are expected to be reserved, well behaved, calm, unambitious and studious. They are therefore made to pursue courses that are in line with these expectations. This edges them out of STEM from early years. On the other hand, when the boys know that academic expectations are high, they strive to meet them. The other dimension to this view is that, teachers may inadvertently raise their grading of girls for the same work and expect girls to work harder to achieve the same output level of boys. These opposing positions actually send the same signal: STEM is for a special breed of people with a certain mental ability.

Teachers' attitudes and expectations are reinforced by those of the parents. Parental influence is so strong that by the time children reach the age of five years, they have already constructed their own gender biased identities about STEM. Parents' educational expectations and involvement in their children's education have been found to positively correlate with learners' educational aspirations (Nichols, Kotchick, Barry \& Haskins, 2010). Children easily follow the direction in which they are steered by their own parents. That is why Dasgupta and Stout (2014) clearly assert that, parents' expectations socialize children's academic trajectories. For instance, children's abilities in Maths are shaped by some of the beliefs that their own parents hold while the performance of adolescent girls is heavily influenced by their mothers' support (Leaper, Farkes \& Brown, 2012). Since mothers unconsciously groom their daughters to be nice wives, they encourage them to think about social science careers which are "soft' compared STEM based careers. This pivotal role that parents play in constructing children's home environment, and influencing their lifestyle behaviors (Lloyd, Lubans, Plotnikoff, Collins \& Morgan, 2014), has a direct bearing not only on their academic interests but also on their achievements.

\section{iii. $\quad$ Role Models and Stereotyping}

It is widely reported that female teachers can positively influence girls' performance as well as engagement in STEM. However, STEM female teachers are in short supply due to the very same factors that hinder enrolment and progression in STEM. This problem is cyclic, spiral and widespread. The proportion of female teachers in maths and sciences is low in many African countries including Kenya. This is because very few female candidates have the necessary background and attain requisite qualification to enroll in these programmes. STEM has traditionally been championed as a male domain, and beliefs about male supremacy in STEM fields (Makarova, et al, 2019) still linger in minds of the students and teachers. In institutions of higher education in Kenya, male students in STEM fields are the worst in stereotyping, and their behaviour is amounts to "STEM bullying." They create a very hostile environment for the female STEM students, and strongly believe the few girls who make it to what they consider "their domain" are not suited for the courses. They regard them as intruders, lazy and incapable of excelling. When these girls perform well, their male counterparts attribute their success to favoritism by lecturers. In the worst scenarios, the male students rally their own classmates against the few female students in STEM disciplines and isolate them during group work. This STEM bullying breaks the emotionally weak and drives them out of STEM courses. Again, although the expectation is that female teachers in STEM act as role models to female students, ironically, this is not always the case. In Kenya, female students have been known to perform dismally in STEM subjects because of the very female teachers assigned to them. As a teacher who has taught both boys and girls at high school level, I observed that girls are sensitive, emotional oriented beings. Emotions on many occasions prevail over logic. When they are uncomfortable with a teacher for 
reasons related or unrelated to content delivery, they lose interest in learning. This is very prevalent in STEM subjects. A female STEM teacher therefore has the big challenge of treading carefully both inside and outside the classroom lest a student develops a negative attitude towards her and by extension the subject she teaches.

\section{iv. Work Environments and Family Obligations}

The poor representation of women in STEM careers is partially occasioned by lack of awareness of certain career options, lack of knowledge about these opportunities, inaccurate information or sheer indecisiveness (Glass \& Minnote, 2010; Schuster \& Martiny, 2016). Although seemingly there has been some improvement in enrolment in STEM fields, this has not translated into similar participation rates in labour market opportunities. According to Silva (2019), women constitute $50 \%$ of the labor market and yet only $28 \%$ of them are in the STEM fields; the rest are men. Landivar (2013) also reports that, women held only a quarter of the jobs in STEM fields in the US despite the fact that they made up almost $50 \%$ of the population. This paints a picture of inflexible, exclusionary, male-dominated work environments that have no place for women. Occupational segregation strongly impacts women's development in STEM fields (Moss-Racusin, Molenda \& Crammer, 2015; Ryan, 2014).

The low numbers of female students in STEM is further compounded by the fact that, those who conceive while at college are forced to defer programs because the STEM courses are practical intensive. These students are unable to balance the demands of motherhood and studying. Deferment affects their transition to the labour market. This problem spirals to the work place where young mothers are unable to balance the parenthood and STEM careers (Cech \& Loy, 2018). As per equality principle, women are expected to work like their male counterparts. This does not always favour women whose roles are multi-faceted while men's roles are linear. For example, whenever there is a difficult decision like raising a family, or nursing a sick member of the family, it is the women who have to make the sacrifice (Nyayieka, 2019). This can put them at loggerheads with their employers and supervisors, and drive many of them out of the STEM jobs. Bernstein (2019) discloses that, after STEM professionals become parents, $43 \%$ of the women switch fields, transition to part-time work or leave the STEM professions. Women also fear that taking STEM courses can affect their job opportunities, promotions at work, getting a spouse and family life (The Conversation, 2018). Generally, the working environment in most STEM fields is harsh in the sense that, it is physically demanding and emotionally draining. At the work place, tasks may require physical exertion that is beyond the capability of women. In addition, women are constantly under watch and being tested so that, when they falter, they indeed prove that they are in wrong fields. As an example of male dominance in certain field, Figure 1 demonstrates the gross imbalance in employment in the manufacturing sector in Kenya over a seven-year period.

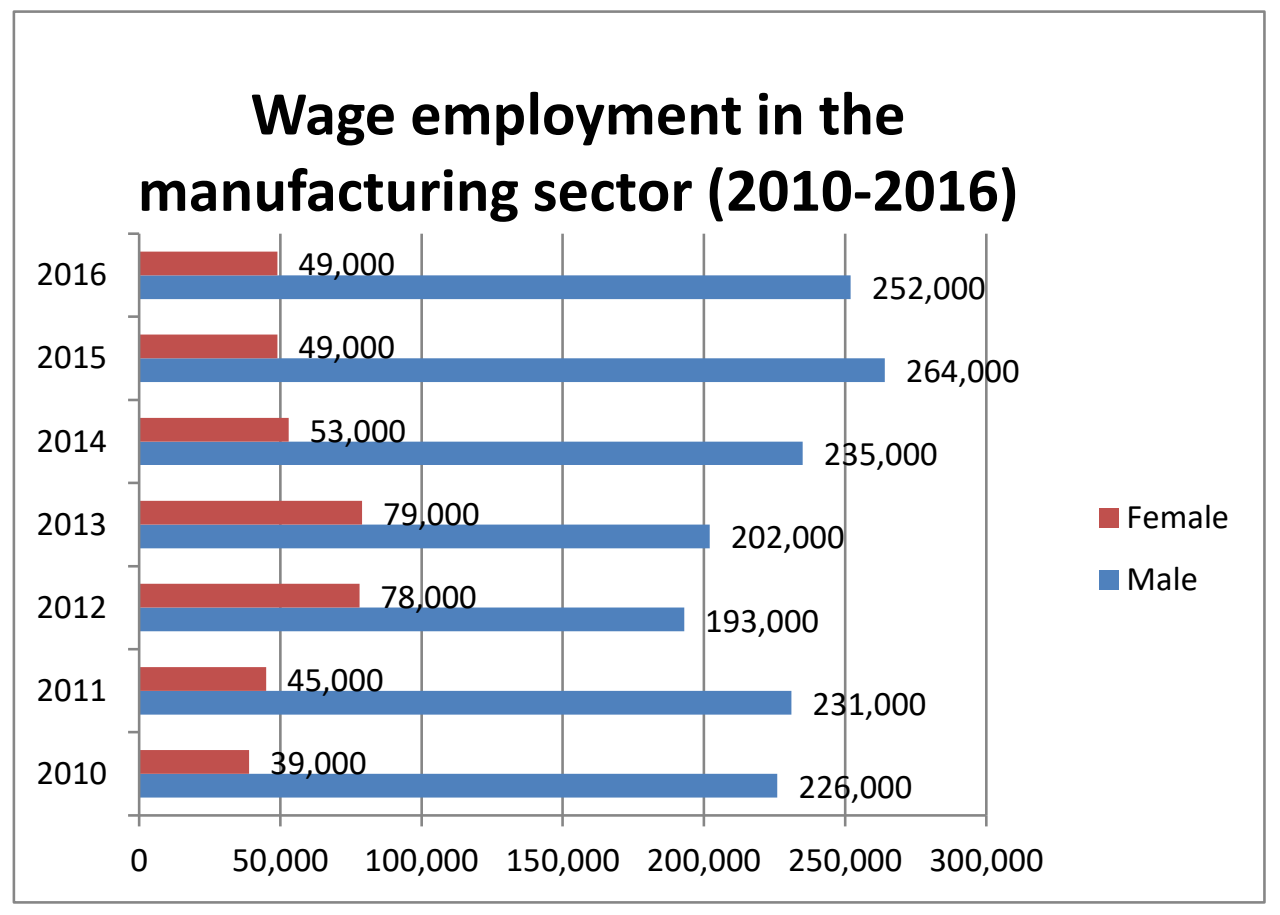

Figure 1. Number of women and men in manufacturing between 2010-2016

Data Source: Kenya National Bureau of Statistics

Figure 1 shows that women are clearly underrepresented in the manufacturing sector, a trend that is likely to be 
reflected across STEM fields. Over a seven-year period, the highest number of women recorded was 79,000 in 2013. However, this was only $28 \%$ of the labour force and men still made up $78 \%$ of the labour force in the manufacturing sector. Unfortunately, this number significantly dropped in subsequent years. On the contrary, men maintained a steady high number which peaked at 264,000 in 2015 out numbering the women by more than five times! During this year, manufacturing sector was made up of $84 \%$ men and only $16 \%$ women. This confirms the likelihood that, women have stayed away from the sector because of the work environment and family obligations. Further evidence of gross underrepresentation of women is depicted in Figure 2 which shows the women and men above 15 in Kenya who have who have trained and qualified in the indicated STEM fields.

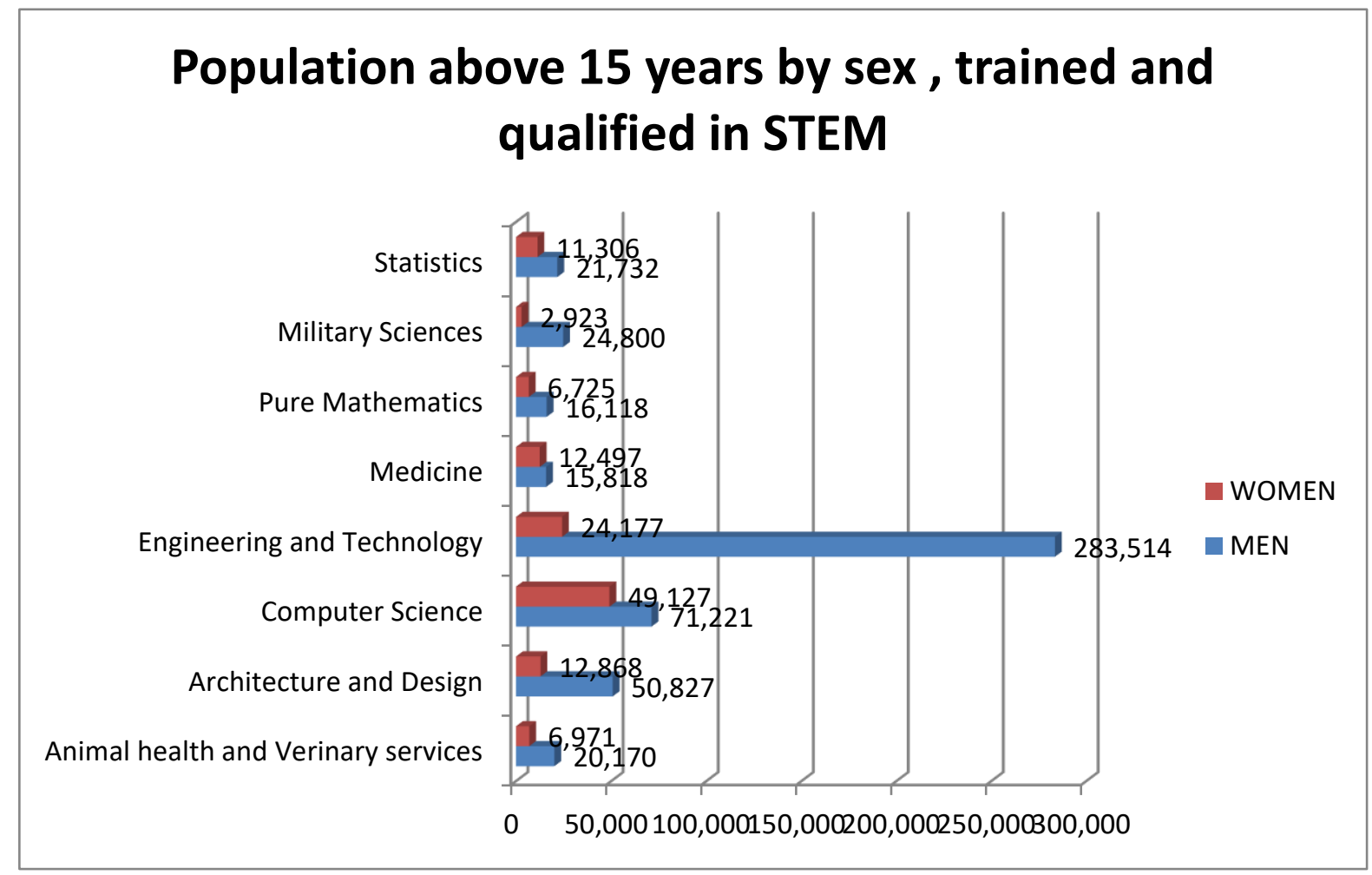

Figure 2. Women and men above 15 in selected STEM fields

Data Source: Kenya National Bureau of Statistics, 2019

Figure 2 above shows, the general representation of women in the selected STEM fields. Of population aged above 15 that has trained and qualified in the indicated STEM fields, it is only in medicine where the disparity between men and women is minimal, with men $(15,818)$, comprising $56 \%$ and women $(12,497)$ comprising $44 \%$. Engineering and technology disciplines have unprecedented disparities with men $(283,514)$ comprising $92 \%$ while women $(24,177)$ make up a paltry $8 \%$. The slightly high percentage in Medicine may be attributable to the care giving nature of the profession that makes it attractive to women.

\section{v. Weak Scholastic performance.}

$\mathrm{Xu}$ (2017) found that, sterling academic performance in major related courses contributed to the likelihood of students working in STEM fields. In Kenya, girls post weak grades in national examinations compared to boys. Since admission into STEM careers is based on this performance, they miss out on great opportunities. During the 2019 KCSE exams, it was reported that female candidates performed well in Arts and Language subjects while boys did well in the sciences (Obiria, 2019). This was reiterated by Otieno (2019) who reported that, female candidates performed better than their male counterparts in English, Kiswahili, CRE, Home Science, Arts \&Design, German and Sign Language. Boys carried the day in Mathematics, Chemistry, Biology, Physics, Geography and History. College and University Admission is pegged on the general performance in KCSE while admission into specific disciplines is determined by subject performance. General performance presupposes specific subject performance, with those who post sterling general performance poised for STEM courses. In 2019, of the 66,661 KCSE candidates who were placed in STEM courses, 42,267 (63.41\%) were male while 24,394 (36.59\%) were female (Nyaundi, 2020).

The table below shows the aggregate general performance by gender in KCSE during the last two years for students who attained the minimum university entry grade. 
Table 1. KCSE University Qualifiers by Gender: 2018-2019

\begin{tabular}{|c|c|c|c|c|c|c|c|c|c|c|c|c|}
\hline \multirow{3}{*}{ Gender } & \multicolumn{6}{|c|}{ Year 2018} & \multicolumn{6}{|c|}{ Year 2019} \\
\hline & \multicolumn{6}{|c|}{ Grade } & \multicolumn{6}{|c|}{ Grade } \\
\hline & A & A- & $\mathrm{B}+$ & B & B- & $\mathrm{C}+$ & A & A- & $\mathrm{B}+$ & B & B- & $\mathrm{C}+$ \\
\hline Male & 201 & 2179 & 5157 & 10036 & 15548 & 20131 & 358 & 3624 & 8221 & 14675 & 20379 & 24714 \\
\hline Female & 114 & 1238 & 3111 & 6367 & 10608 & 15687 & 269 & 2172 & 5145 & 9803 & 14961 & 21425 \\
\hline Total & 315 & 3417 & 8268 & 16403 & 26156 & 35818 & 627 & 5796 & 13366 & 24478 & 35340 & 46139 \\
\hline
\end{tabular}

Source: KNBS, 2020; KNEC,

Table 1 shows that more boys than girls qualified for university admission. In 2018, 53,252 (59\%) of those qualified were boys compared to 37,125 (41\%) girls. Although the there was an improvement of qualifiers of both gender in 2019, still 71,971 (57\%) boys qualified compared to 53,775(43\%). Although the number of girls who qualify is slowly increasing, it has failed to keep pace with that of boys. A similar trend is likely to be reflected in STEM admissions.

The graphic presentation in Figure 3 and Figure 4 show the trend in performance.

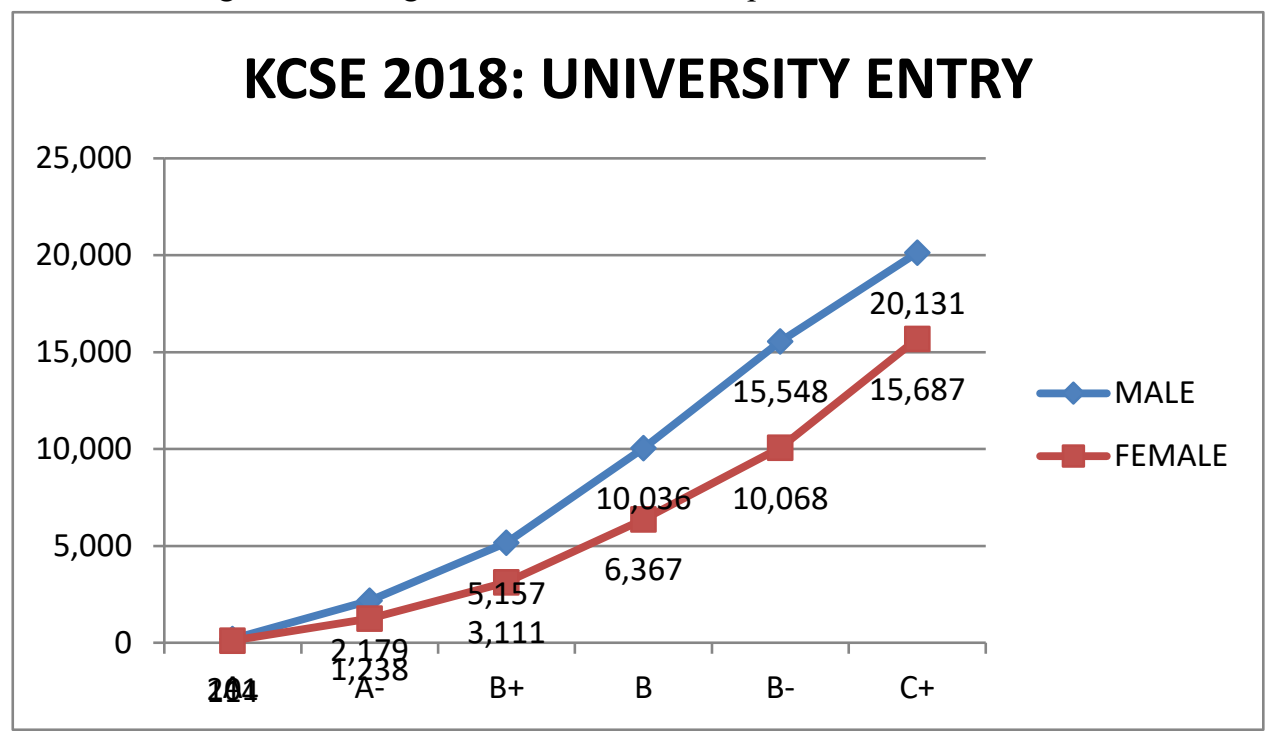

Figure 3. University attainment by boys and girls in KCSE 2019

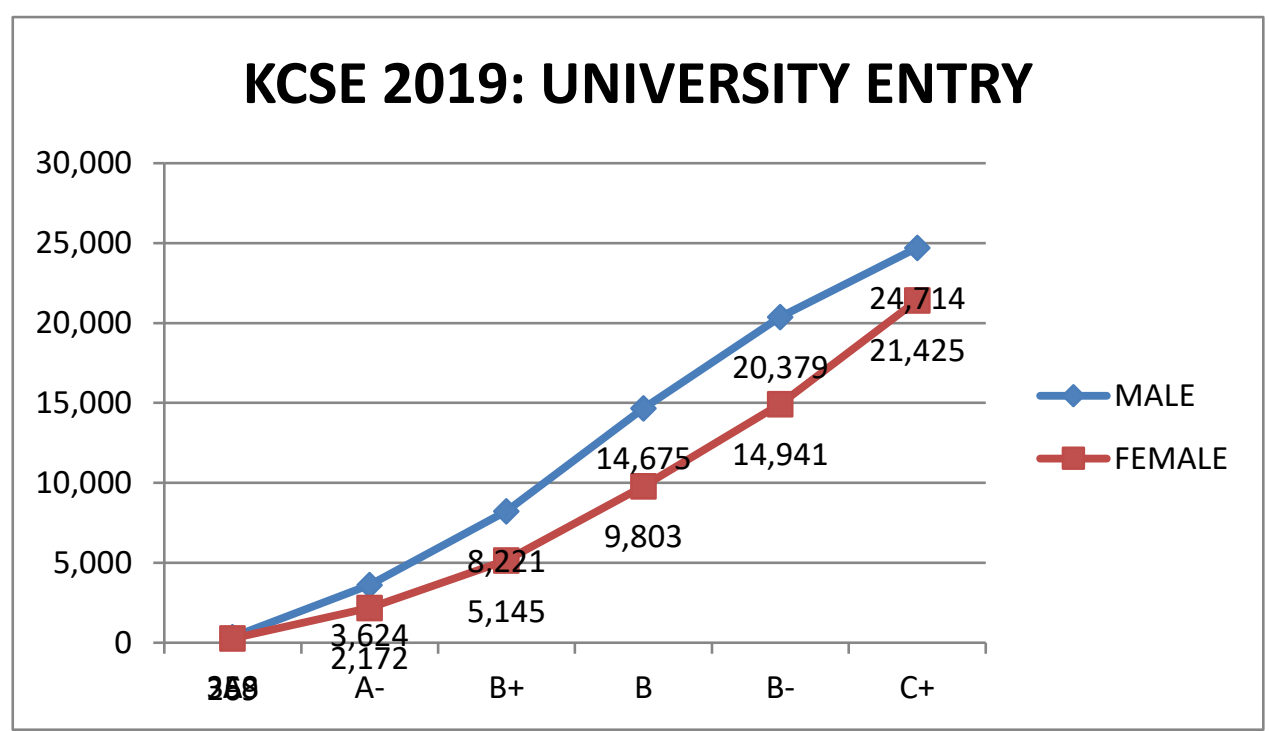

Figure 4. University attainment by boys and girls in KCSE 2019 
Figure 3 and Figure 4 show that boys outperformed girls in KCSE during 2018 and 2019. Candidates who score Mean Grades A, A- and B+ have high chances of admission in STEM fields compared to the rest. This means in $2018,63 \%$ of the boys $(7,537)$ stood a higher chance of gaining admission in STEM compared to $37 \%(4,463)$ of the girls. A similar scene played out with $62 \%(12,203)$ of the top performing boys assured of STEM compared to $38 \%(7,586)$ of the girls. While the girls' top grades are on an upward trend, they are not significantly rising to be at par with or surpass those of the boys.

There are other disciplines that are expected to drive the Big Four Agenda and Sustainable Development Goals also examined at KCSE. Kajilwa (2020) reports that, in 2017,281 students registered for building and construction. However, only 12 were female. In 2018, of the 292 candidates who registered for the same course, 290 were male. In 2018, Power Mechanic had 166 candidates and only 5 were female and of the 220 in 2018, only 12 were female.

\section{STEM and Sustainable Development Goals}

Sichangi (2017) is categorical that, girls and women need to play a significant role in attainment of SDGs, and this includes getting more of them into Science, Technology, Engineering and Mathematics (STEM) studies and jobs. Essentially, SDG number five (Gender equality and empowerment of all women and girls) is hinged on equal opportunities for men and women. Inability to provide this in STEM sets back the realization of this goal. STEM is thus expected to leverage the attainment of this Sustainable Development Goal. The future of nations, developing and developed alike, lies in their potential to harness STEM for practical solutions that will drive economic growth and boost Gross National Products (GDPs). STEM is needed to drive the realization of SDG number eight: Decent work and Economic growth. This should be achieved through provision of right mix of knowledge and skills. Failure to have women as active participants in STEM in large numbers decelerates the pace at which this SDG can be achieved. Secondly, underrepresentation of women in STEM will affect SDG number one: No poverty. Women will continue to suffer poverty due to unequal access to economic resources. Being locked out of STEM because of the numerous drivers mentioned above puts them in a precarious economic position. The broad array of emerging technologies that help achieve food security and improve nutrition like synthetic biology, artificial intelligence, genetic engineering, remote sensing and computer science exclude most women because they are STEM based. Again, as most jobs skew towards STEM skills, women are likely to suffer unemployment effects that will aggravate poverty levels. Thirdly SDG number two: zero hunger will be affected. Hunger and poverty are twins. Poverty breeds hunger and hunger has the face of a woman. Low access to STEM will in turn restrict women's access to and utilization of technologies that can boost productivity. This will have a disempowering effect permeating the entire aspect of women's life from health to the general well-being and with spillover effects on their families. It can also easily redress the gains so far made in alleviating extreme hunger and poverty. Science is a foundation of well-paying jobs. A financially empowered woman has economic security, and is equipped with great social and political voice. Families, societies and economies depend on women's work. If their ability and potential in STEM is untapped, it is to the disadvantage of all. This affects the realization of SDG number three: good health and wellbeing because women are at the core of families. Knowledge economies run on STEM and drive the SDGs which are about inclusive and sustainable societies in which everyone thrives. STEM and trade are powerful forces driving progress and expected to lead to poverty reduction and overall human development. For as long as STEM fields have a low female uptake, the realization of SDGs remains a mirage.

\section{STEM and the Big Four Agenda}

The Big Four Agenda is a four pronged strategy entailing manufacturing, universal healthcare, food security and affordable housing. It is meant to put Kenya on track for the realization of Vision 2030 and the achievement of SDGs. This underscores investment in STEM programs. The manufacturing sector is crucial for the achievement of vision 2030 and job creation. It is acknowledged that manufacturing remains the biggest platform for job creation, expected to create 1.3 million jobs by 2022. However the current skills gap, STEM deficiency and STEM gender disparity wage a silent war against this expectation. To have products that compete favourably on the global market, Kenyan industries need to embrace modern manufacturing trends which can only borne out of $21^{\text {st }}$ century skills, top of which are STEM based courses. When the manufacturing base is strong, efficient and innovative, it can tremendously drive the country's economy and hasten the country's aspiration of being a middle-income industrializing economy. However, low representation in women in STEM skills means underutilization of their potential in innovation and creativity in this sector. The information on labour force distribution within the manufacturing sector indicates that this aspect of the Big Four Agenda could be a non-starter.

The agricultural sector has the highest uptake of women and food security is one of the Big Four Agenda pillars. Factors that lower food production and threaten food security like low and declining soil fertility, poor seed quality and pests would benefit from women's enrolment and persistence in STEM so that, they can combine research efforts with their male counterparts on how to improve seed quality, enrich soils and fight pests. The agricultural sector has great opportunities for innovations that enhance food security for instance drought and pest resistant crops, and production of 
fast-growing seeds. This sector has been attractive to women at all its points. STEM knowledge would equip them to be more productive and, in the process, assure food security, alleviate poverty and hunger. When these are achievement at home front, there is a spillover effect to the nation.

The quality of health services should be good enough to improve the health of those receiving the services. In Kenya, this is compromised by low staffing and capacity gaps. While the health sector has a significant number of women there is still need for more women with appropriate STEM skills. A pronounced presence of women in health means a healthier and more productive nation.

Kenya's shortage of housing contributes to expansion of slums which in turn leads to ill health because of the conditions within the slum settings. Enablers of affordable housing like construction require the right skills. There is also need for research on affordable building materials if the country's dream of providing 500,000 units by 2022 is to be realized. This effort would benefit from women with a knowhow in STEM working on innovative projects with male counterparts.

\section{Why Mitigate STEM Gap Drivers}

It is important to institute measures that can narrow the gender STEM gap. In this $21^{\text {st }}$ Century, STEM innovations are taking centre stage in the face of modern challenges related to issues of climate change, health and inequality. Technology is advancing at a very rapid speed and the labour market expectations are continually changing. This requires innovative minds that can only be born out of STEM. The looming crisis in industry due to the lack of a STEM-trained workforce (Wilson \& Mack, 2014), can be stemmed by having more women in STEM careers.

STEM education enhances economic growth by creating critical thinkers and a generation that innovates new products and processes that sustain economies (Genoways, 2014; UNESCO, 2019). STEM has the capacity to spur inventions and in the process, open up discoveries that bring forth new job as well as economic opportunities. In most of the economies, it is STEM Jobs that are high paying and in high demand. A report by the World Economic Forum covering 20 countries had predicted the loss of jobs in millions due to disruptive labor market changes and Otieno (2019) reports that, there will be an overwhelming requirement for STEM skills-based jobs. Rajput (2019) reiterates that jobs which are significantly based on and enhanced by technology are likely to see a surge in demand during the next 10 years. These specializations include data analysis, science, software applications developers, process automation experts, robotics engineers etc. It is these STEM based jobs that will drive economic growth and reduce unemployment rates across the globe.

Although some of the women who have ventured into STEM fields have been frowned upon for intrusion into the male domain, there have been rewards for those who have dared make the move (Mbirianjau, 2018). This is in the sense that, they have had more options than men with similar abilities and enjoyed enhanced salaries. It is therefore important that women get into STEM fields because a typical STEM worker earns two-third more than those employed in other fields. Sadly, some of the highest paying STEM jobs like computer science and engineering have few women workers. Milgram (2011) regards the absence of women from STEM as a missed opportunity for those fields because they bring unique perspectives which shape and influence the STEM disciplines and the entire society. Underrepresentation of women in STEM translates into serious loss of critical mass of talent (UNESCO, 2017). Blackburn (2017) clearly states that, representation of women in STEM is important because it creates diversity in the workforce which in turn contributes to creativity, productivity, innovation and success. The combined experiences of women and men can effectively inform and guide the direction of engineering and technical innovation (Corbett \& Hill, 2015). To meet work force supply demands, improve innovation and assure equity, STEM fields require the creativity and talent of both boys and girls. Gender diverse companies are more likely to financially outperform their competitors' mix of the gender mix in ideas and innovativeness.

Women have been applauded for some of the most significant breakthroughs that have shaped the world today. Thorntorn (2020) mentions Marie Curie's radiation discoveries, Grace Hooper's work on computer programming and Barbara McClintok's pioneering work in genetics. This proves that women have the potential for new discoveries. While there will be obstacles along the way, none is insurmountable. Rae (2018) reiterates that, without female inventors, we would not have windshield wipers, coffee filters and disposable diapers. Additionally, it is indicated that, recent technology which has come from the girl child is a Smartphone attachment that lets parents diagnose ear infections and an inexpensive water purifier (Ibid). This demonstrates that, women given a chance can through their innovations provide solutions to societal problems. Furthermore, the fact that the medical field has a fairly good representation of women shows that, women have the capacity for the STEM rigor.

\section{Conclusions}

From the review carried out, it is concluded that, there is general underrepresentation of women in STEM careers. Contributing factors include self-concept and lack of resilience, teachers' and parental expectations, role models and 
stereotyping, work environments and family obligations, and weak scholastic performance. It is also concluded that, this underrepresentation of women in STEM is likely to hinder achievement of the Sustainable Development Goals like hunger and eradicating poverty. Additionally, the Big Four Agenda may not be realized because it requires harnessing the ability of both genders. Consequently, Vision 2030 will remain an illusion. It is therefore important to stem the gender STEM gap drivers and revamp economies.

\section{Recommendations}

This section presents practical measures to mitigate the gender STEM gap. It is hoped that these measures and approaches can help female students navigate the STEM gap drivers, successfully complete their courses, transition to the world of work and remain in the STEM based professions for as long as they should so that in the process, their resilience becomes the magnet that draws others into STEM.

\section{i. Parental Roles}

Exclusion begins at childhood and therefore inclusion must begin at the same point. Parents have an immense role to play in this inclusion process by deconstructing the stereotypes. They have to make girls know and understand that they can be achievers in STEM. This calls for a change in the way they socialize girls as well as their expectations of them. Opportunities for discovery, creation and growth should be available on the home front at the earliest years.

\section{ii. Teachers}

There is need to have highly competent and professional teachers in STEM to serve as role models and kill the stereotyping. These role models ought to be visible at various stages in the careers of female learners (basic education, post-secondary education and work place). The teachers must constantly emphasize that, STEM is for everyone; it is not a preserve of the boys. They have to debunk the myth that, there are gender disparities in mental abilities and brain power which affect students' STEM placement and performance. Teachers need to be more patient with students who are not quick STEM learners but can excel if given the opportunity.

\section{iii. Students}

Female students at the basic education level must be sensitized to the realization that, the current and future job market is skewed towards STEM. That immediate exposure to STEM skills is an immediate and urgent requirement. That STEM is slowly becoming the lever/fulcrum upon which the world is rotating.

Women enrolled in STEM fields in higher education and subjected to discrimination and "STEM bullying" by male classmates should band together within and across the STEM disciplines. This will act as safety net providing them with the emotional support they need to soldier on. Since the disciplines are intertwined, they can tap into each other's strengths and eventually survive the college "STEM storms". These women should also learn to cheer themselves on, recognize and appreciate each milestone, and use it as a spring board to the next level. They should realize and appreciate the fact that, at the moment, industry favours them when they have the same credentials like men and leverage this to increase their numbers in STEM professions. They can then ride on the social STEM capital for visibility and progress within the profession.

\section{vi. Institutions}

Each institution of higher education should have a science endowment fund to support at least a given percentage of girls every academic year pursue STEM disciplines. This fund should target girls with an eye on STEM but whose financial ability is limited although they meet the minimum STEM admission requirements. Higher education institutions must institute clear policies against STEM bullying and punish perpetrators. STEM female representatives in key positions within the Students' Councils can act as the voices of the voiceless.

\section{v. Industry}

Organizations need to put in place strategies and policies that favour retention of women. Silent discrimination practices in organizations should be outlawed. A trade off of equality for equity to enhance fairness can ameliorate the problem of women quitting STEM professions. Strategies and policies that enhance equity for female workers could also boost STEM female workers.

Industries should increase their uptake of female STEM graduates. Meeting the $30 \%$ female representation constitutional requirement is one step towards marketing women in STEM fields. Absorbing female STEM students in internships and grooming them to successfully transition to the labour market on upon hire could encourage them to be persistent. 


\section{References}

Baxter, K. B. (2010). Women in science and engineering: Thriving or surviving? https://search.proquest.com/openview/f3b8e6999d1fd819d11aecc5df76c34c/1?pq-origsite=gscholar\&cbl=18750\& $\operatorname{diss}=y$

Beede, D., Julina, T., Langdon, D., McKittrick, G., Khan, B., \& Doms, M. (2011). Women in STEM: A Gender Gap to Innovation. Economics and Statistics Administration, 11(4). https://doi.org/10.2139/ssrn.1964782

Bernstein, R. (2019, February 18). After a baby, $28 \%$ of new parents leave full-time STEM work. https://doi.org/10.1126/science.caredit.aax0346

Blackburn, H. (2017) The Status of Women in STEM in Higher Education: A Review of the Literature 2007-2017, Science \& Technology Libraries, 36:3, 235-273. https://doi.org/10.1080/0194262X.2017.1371658

Cech, E. A., \& Blair-Loy, M. (2019). The changing career trajectories of new parents in STEM. PNAS, 116(10), 5182-4187. https://doi.org/10.1073/pnas.1810862116

Clandfield, D., \& Martell, G. (2014). Restacking the deck: Streaming by class, race and gender in Ontario schools. Ottawa, ON: Canadian Centre for Policy Alternatives.

Corbett, C., \& Hill, C. (2015). Solving the equation: The variables for women's success in engineering and computing. Washington, DC: American Association of University https://www.aauw.org/files/2013/02/Why-So-Few-Women-in-Science-Technology-Engineering-and-Mathematics. pdf

Corbett, C., Hill, C., \& St. Rose, A. (2010). Why so few? Women in science, technology, engineering and mathematics.

Dasgupta, N., \& Stout, J. G. (2014). Girls and Women in Science, Technology, Engineering, and Mathematics: STEMing the Tide and Broadening Participation in STEM Careers. Policy Insights from the Behavioral and Brain Sciences, 1(1), 21-29. https://doi.org/10.1177/2372732214549471

Frank, K. (2019). A gender Analysis of Occupational Pathways of STEM Graduates in Canada. Statistics Canada, Analytical Studies Research Paper Series, September 16, 2019.

Frome, P. M., Alfeld, C. J., Eccles, J. S., \& Barber, B. L. (2006). Why don't they want a male-dominated job? An investigation of young women who changed their occupational aspirations. Educational Research and Evaluation, 12(4), 359-372. https://doi.org/10.1080/13803610600765786

Genoways, S. (2014). The Role of High Schools in Preparing Young Women for a STEM Career. University of Nebraska at Omahar from https://www.unomaha.edu/college-of-education-health-and-human-sciences/moec/_files/docs/edad-9550-final-rese arch-brief-genoways-spring2014-corrected-1-26-14.pdf

Glass, C., \& Minnotte, K.1. (2010). Recruiting and hiring women in STEM fields. Journal of Diversity in Higher Education, 3(4), 218-229. https://doi.org/10.1037/a0020581

Hango, D. (2013). Gender differences in science, technology, engineering, mathematics and computer science (STEM) programs at university, http: www.statcan.gc.ca/reference/copyright-droit-auter-eng.htm

Hansen, M. L. (2018). Examining ways to meaningfully support students in STEM. International Journal of STEM Education. Article no. 53.

He, L., Zhou, G., Salinitri, G., \& Xu, L (2011). Female Underrepresentation in STEM Subjects: An Exploratory Study of Female High School Students in China. EURASIA Journal of Mathematics, Science and Technology Education, 2020, 16(1), 1-13. https://doi.org/10.29333/ejmste/109657

Kajilwa, G. (2019, December 27). Report: KCSE students keeping off technical subjects. https://www.standardmedia.co.ke/author/graham-kajilwa

Kimotho, J. (8 March 2019). Bridging the gender equality gap in STEM to fully transform Africa. www.adeanet.org/eu/users/Juliet-kimotho

Landivar, L. C. (2013). Disparities in STEM employment by sex, race and hispanic origin. http://www.census.gov/prod/2013pubs/acs-24.pdf

Leaper, C., Farkas, T., \& Brown, C. S. (2012). Adolescent girls' experiences and gender-related beliefs in relation to their motivation in math/science and English. Journal of Youth and Adolescence, 41, $268-282$. https://doi.org/10.1007/s10964-011-9693-z 
Lloyd, A. B., Lubans, D. R., Plotnikoff, R. C., Collins, C. E., \& Morgan, P. J. (2014). Maternal and paternal parenting practices and their influence on children's adiposity, screen-time, diet and physical activity. Appetite, 79, 149-157. https://doi.org/10.1016/j.appet.2014.04.010

Makarova, E., Aeschlimann, B., \& Herzog, W. (2019) The Gender Gap in STEM Fields: The Impact of the Gender Stereotype of Math and Science on Secondary Students' Career Aspirations. Front. Educ. 4(60). https://doi.org/10.3389/feduc.2019.00060

Mbirianjau, L. W. (September, 26 2018). Why fewer Kenyan women are choosing degrees in STEM. The Conversation. https://www.weforum.org/agenda/authors/lucy-wandiri-mbrianjau

McKenna, C. (2018, February 9). Charts of the week: Advancing women and girls in science. https://www.brookings.edu/author/chris-mckenna/

Milgram, D. (2011). How to recruit women and girls to the science, technology, engineering, and math (STEM) classroom. Technology and Engineering Teacher, 71(3), 4-11. Retrieved from http://search.proquest.com.leo.lib.unomaha.edu/docview/964179602?accountid=14692

Moss-Racusin, C. A., Molenda, A. K., \& Cramer, C. R. (2015). Can evidence impact attitudes? Public reactions to evidence of gender bias in STEM fields. Psychology of Women Quarterly, 39(2), 194-209. https://doi.org/10.1177/0361684314565777

National Girls Collaborative (2020). NSF Women, Minorities, and People with disabilities in Science and Engineering, https://www.nsf.gov/statistics/2015/nsf15311

Ng'ang'a, A., Mureithi, L. P., \& Wambugu, A. (2018) Mathematics gender gaps in Kenya: Are resource differentials between boys and girls to blame? Cogent Education, 5(1), 1564163; https://doi.org/10.1080/2331186X.2018.1564163

Nichols, T. M., Kotchick, B. A., Barry, C. M., \& Haskins, D. G. (2010). Understanding the educational aspirations of African American adolescents: Child, family, and community factors. Journal of Black Psychology, 36(1), 25-48. https://doi.org/10.1177/0095798409344084

Nyaundi, L. (2019, December 19) KCSE 2019: Fallen giants back as A's double. https://www.the-star.co.ke/authors/lewis-nyaundi

Nyayieka, I. (2019, February 10). Women in Kenya closing gender gap in science and tech. Business Daily

Obiria, M. (2019, December 20). Concerns raised on girls' dismal performance in STEM subjects. https://www.nation.co.ke/Kenya/moraa-obiria-222848

OECD (2015). The ABC of gender equality in education: aptitude, behavior, confidence. PISA, OECD Publishing. https://doi.org/10.1787/9789264229945-en

Okeke, I, N., Babalola, P. C., Byarugaba, K. D., Djimde, A., \& Osoniyi, R. O. (2017). Braodening Participation in the Sciences within and from Africa: Purpose, Challenges, and Prospects. CBC Life Sciences Education, 16(2). https://doi.org/10.1187/cbe.15-12-0265

Otieno, R. (2019, December 19). Boys reclaim their lost glory to beat girls in KCSE. https://www.standardmedia.co.ke/author/rawlings-otieno

Rae, K. (2018, October 3). Why girls need STEM and why STEM needs girls. https://www.todaysparent.com/author/kate-rae/

Rajput, R. (2019). Entrenching STEM education in Africa. https://www.the-star.co.ke/the-star/opinion/star-blogs/

Ryan, M. (2014). Who is like a scientist? A self-prototype matching approach to women's underrepresentation in STEM fields. Ph.D., University of Washington

Schuster, C., \& Martiny, S. (2016). Not feeling good in STEM: Effects of stereotype activation and anticipated effect on women's career aspirations. Sex Roles, 76(1-2), 40-55. https://doi.org/10.1007/s11199-016-0665-3

Sichangi. M. (2017). Why are girls and women under-represented in science related fields in Africa? https://www.globalpartnership.org/users/msichangi

Silva, V. (2019). 8 statistics and Facts about women in STEM. The Learning Centre

Simon, R. M., Wagner, A., \& Killion, B. (2017). Gender and choosing a STEM major in college: Femininity, masculinity, chilly climate, and occupational values. Journal of Research in Science Teaching, 54(3), 299-323. https://doi.org/10.1002/tea.21345 
The Conversation (2018, September 23). Why fewer Kenyan women are choosing, completing STEM courses. The Conversation

Thornton, A. (2019). Gender equality in STEM is possible. These countries prove it. https://www.weforum.org/agenda/authors/alex-thornton

UNESCO (2017) Cracking the code: Girls' and Women's education in science, technology engineering and mathematics (STEM). France: UNESCO

UNESCO (2019). Women in Science. Fact Sheet No. 55 June 2019 FS/2019/SCI/55. https://doi.org/10.18356/cb3dbe0d-en

Williams, S. (2020, February 11). Opinion: Let's get more girls into STEM - for them and for us all. Devex

Wilson, R., \& Mack, J. (2014). Declines in high school mathematics and science participation: Evidence of students' and future teachers' disengagement with maths. International Journal of Innovation in Science and Mathematics, $22(7), 35-48$.

Xu, Y. J. (2017). Attrition of women in STEM: Examining job/major congruence in the career choices of college graduates. Journal of Career Development 44 (1), 3-19. https://doi.org/10.1177/0894845316633787

Zachmann, K. (2018). Women in STEM: Female Role Models and Gender Equitable Teaching Strategies. Retrieved from Sophia, the St. Catherine University repository website: https://sophia.stkate.edu/maed/272

\section{Copyrights}

Copyright for this article is retained by the author(s), with first publication rights granted to the journal.

This is an open-access article distributed under the terms and conditions of the Creative Commons Attribution license which permits unrestricted use, distribution, and reproduction in any medium, provided the original work is properly cited. 